Journal of Animal Ecology 2001, 70, $1-13$

\section{Life path analysis: scaling indicates priming effects of social and habitat factors on dispersal distances}

\author{
R. E. KENWARD*, S. S. WALLS $†$ and K. H. HODDER* \\ *Centre for Ecology and Hydrology, Winfrith Technology Centre, Dorchester, Dorset DT2 8ZD, and $\dagger$ Biotrack \\ Ltd, 52 Furzebrook Road, Wareham, Dorset BH20 5AX, UK
}

\begin{abstract}
Summary
1. Movements of many animals along a life-path can be separated into repetitive ones within home ranges and transitions between home ranges. We sought relationships of social and environmental factors with initiation and distance of transition movements in 114 buzzards Buteo buteo that were marked as nestlings with long-life radio tags.

2. Ex-natal dispersal movements of 51 buzzards in autumn were longer than for 30 later in their first year and than 35 extra-natal movements between home ranges after leaving nest areas. In the second and third springs, distances moved from winter focal points by birds that paired were the same or less than for unpaired birds. No postnuptial movement exceeded $2 \mathrm{~km}$.

3. Initiation of early ex-natal dispersal was enhanced by presence of many sibs, but also by lack of worm-rich loam soils. Distances travelled were greatest for birds from small broods and with relatively little short grass-feeding habitat near the nest. Later movements were generally enhanced by the absence of loam soils and short grassland, especially with abundance of other buzzards and probable poor feeding habitats (heathland, long grass).

4. Buzzards tended to persist in their first autumn where arable land was abundant, but subsequently showed a strong tendency to move from this habitat.

5. Factors that acted most strongly in $1 / 2-\mathrm{km}$ buffers round nests, or round subsequent focal points, usually promoted movement compared with factors acting at a larger scale. Strong relationships between movement distances and environmental characteristics in $1 / 2-\mathrm{km}$ buffers, especially during early ex-natal dispersal, suggested that buzzards became primed by these factors to travel far.

6. Movements were also farthest for buzzards that had already moved far from their natal nests, perhaps reflecting genetic predisposition, long-term priming or poor habitat beyond the study area.
\end{abstract}

Key-words: Buteo, buzzard, natal, nuptial, soils.

Journal of Animal Ecology (2001) 70, 1-13

\section{Introduction}

The movements of an animal form a path that is continuous throughout its life (Baker 1978). Different types of movement are studied by estimating distances or areas covered along that life path. Frequent movements, such as those between foraging and roosting sites, or infrequent, but extreme movements, such as migration, have long been defined from visual observations (von Hohenstaufen 1248). Early definitions of

Correspondence: R. E. Kenward, Centre for Ecology and Hydrology, Winfrith Technology Centre, Dorchester, Dorset DT2 8ZD, UK. E-mail: reke@ceh.ac.uk dispersal (Howard 1960) were extended by systematic marking of individuals: natal dispersal distances travelled from birth sites were then separated from breeding dispersal movements between nests (Greenwood 1980). Trapping and marking also provided the concept of a home range, as an area traversed during an animal's normal activities between dispersal movements (Burt 1943)

Long-life radio tags enable us to look at movements of individuals in even more detail, which can make it necessary to re-examine earlier definitions. For example, home ranges are not static: they may continually expand due to excursions or drift across the landscape (Doncaster \& Macdonald 1991; Gautestad 
2

R.E. Kenward,

S.S. Walls \&

K.H. Hodder

\& Mysterud 1995). This difficulty can be resolved by defining home range as an area repeatedly traversed within a life path (Kenward 2001), and if necessary adding a time-frame to give seasonal and annual home ranges (Cooper 1978; White \& Garrott 1990). Annually repeated transitions between separate home ranges then represent migration. However, other movements between successive home ranges are hard to fit into a simple framework of natal and nuptial dispersal.

For example, buzzard Buteo buteo life paths may contain several transition movements, to separate home ranges, between the natal area and any breeding area (Walls \& Kenward 1998). This is true of many vertebrates, although some drift more than buzzards or remain nomadic (Glover 1952; Baker 1978; Lidicker $\&$ Stenseth 1992).

Modelling movements is a step towards building individual-based models to predict population processes (Sutherland \& Allport 1994; Goss-Custard et al. 1995a,b; Sutherland 1996), especially colonization (Rushton et al. 1997). Prediction of re-colonization is especially important for conserving large raptors, which often have populations restricted by human activities (Newton 1979). However, such modelling requires an understanding of the mechanisms that affect movements along life paths. Factors affecting dispersal have been investigated for bird and mammal movements from natal sites (e.g. Holleback 1974; Davies 1976; Macdonald 1983; Alonso et al. 1987; Bustamente \& Hiraldo 1990; Lidicker \& Stenseth 1992; Larsen \& Boutin 1994), in a few cases with experiments to test causality (e.g. Davies 1978; Nilsson 1990; Kenward, Marcström \& Karlbom 1993). However, factors affecting subsequent non-migratory movements are difficult to study at the individual level, due to social pressures and environmental factors that are hard to measure at appropriate scales (Turchin 1998).

Radio tags that last up to 4 years now make it possible to study individual life-paths from natal areas to first breeding (Walls \& Kenward 1998). Land cover data mapped from satellite images (Fuller, Groom \& Jones 1994a; Fuller, Groom \& Wallis, 1994b) can be used as covariates in analyses of home ranges and transition movements. Data on local density of nonbreeding individuals can also be provided by extensive radio tagging. In this paper, we analyse factors that affected transition movements along the life paths of buzzards in Dorset, England, from natal sites, from subsequent home ranges before breeding and between breeding sites. We show that movements are associated with environmental and social factors that vary in season and scale of influence.

\section{Methods}

2001 British

Ecological Society, Journal of Animal

Ecology, 70,
The study area, centred at E2 $2^{\circ} 30^{\prime} \mathrm{N} 50^{\circ} 42^{\prime}$, was a $6 \times 22-\mathrm{km}$ strip chosen in southern England to maximize habitat diversity. The main land cover combinations (Fig. 1, Appendix 1) were grassland (45\% of the area), deciduous and coniferous woodland (15 and 10\%), arable farmland $(12 \%)$, and heathland, rough ground or scrub $(12 \%)$. Bands of these habitats tend to run east to west across the study area and continue into the adjacent areas. Six per cent of the study area was developed as towns, villages, quarries or other unvegetated areas.

\section{RADIO TAGGING AND TRACKING}

All nests in the study area were sought during 1990 94. Just before young buzzards left the nest, they were sexed from tarsal width (Walls \& Kenward 1995) and 130 were fitted with 30 -g backpack radio tags on a harness of 6-mm wide Teflon ribbon (Dunstan 1972). During 1990-91, backpack tags transmitted for approximately 2 years, and later tags for 4 years. In 1990-91, 16 radio tags were tail-mounted on buzzards caught 3 weeks after they had left the nest. These 12-g tags were sown into two central tail feathers after completion of shaft growth (Kenward 1978); they transmitted for less than a year before being moulted, together with the feathers, in the following spring. All radio tags (from Biotrack Ltd, Wareham, Dorse BH20 5AX, UK) were fitted with posture sensors that indicated an upright (e.g. perching) or horizontal (e.g. flying or brooding) position.

Locations of buzzards were recorded to within $100 \mathrm{~m}$ by triangulation, from within $1 \mathrm{~km}$ using a three-element hand-held Yagi antenna or from within $2 \mathrm{~km}$ using a six-element Yagi on a 6-m telescopic mast fitted to a Landrover. All buzzards were tracked twice weekly from June until late September during 1990-92, and once a week during the same season in 1993-94. The frequency of checks from October declined over the years: once weekly in 1990-91, once a fortnight in 1992, once monthly in 1993 and four times a year from May 1995 (Walls \& Kenward 1998). Radio tagged females were checked for breeding during early May. All buzzards were approached on foot during April and May to determine if the bird was associated with a nest, in which case it was defined as breeding, or was vocal in a territorial manner and with a mate, in which case it was considered paired Nests were checked during June to establish whether or not young were raised.

Early movements in previous studies have been called post-fledging dispersal (Alonso et al. 1987; Eden 1987), juvenile dispersal (Gonzalez et al. 1989) or winter dispersal (Haig \& Orring 1988; Warkentin \& James 1990). Here, we retain the terminology of Greenwood (1980) and use consistent Latin. We define ex-natal movements as those away from the natal area to the home range in which individuals first settled and extra-natal movements as those from that or any subsequent home range. Spring movements that resulted in pairing or nesting were regarded as prenuptial.
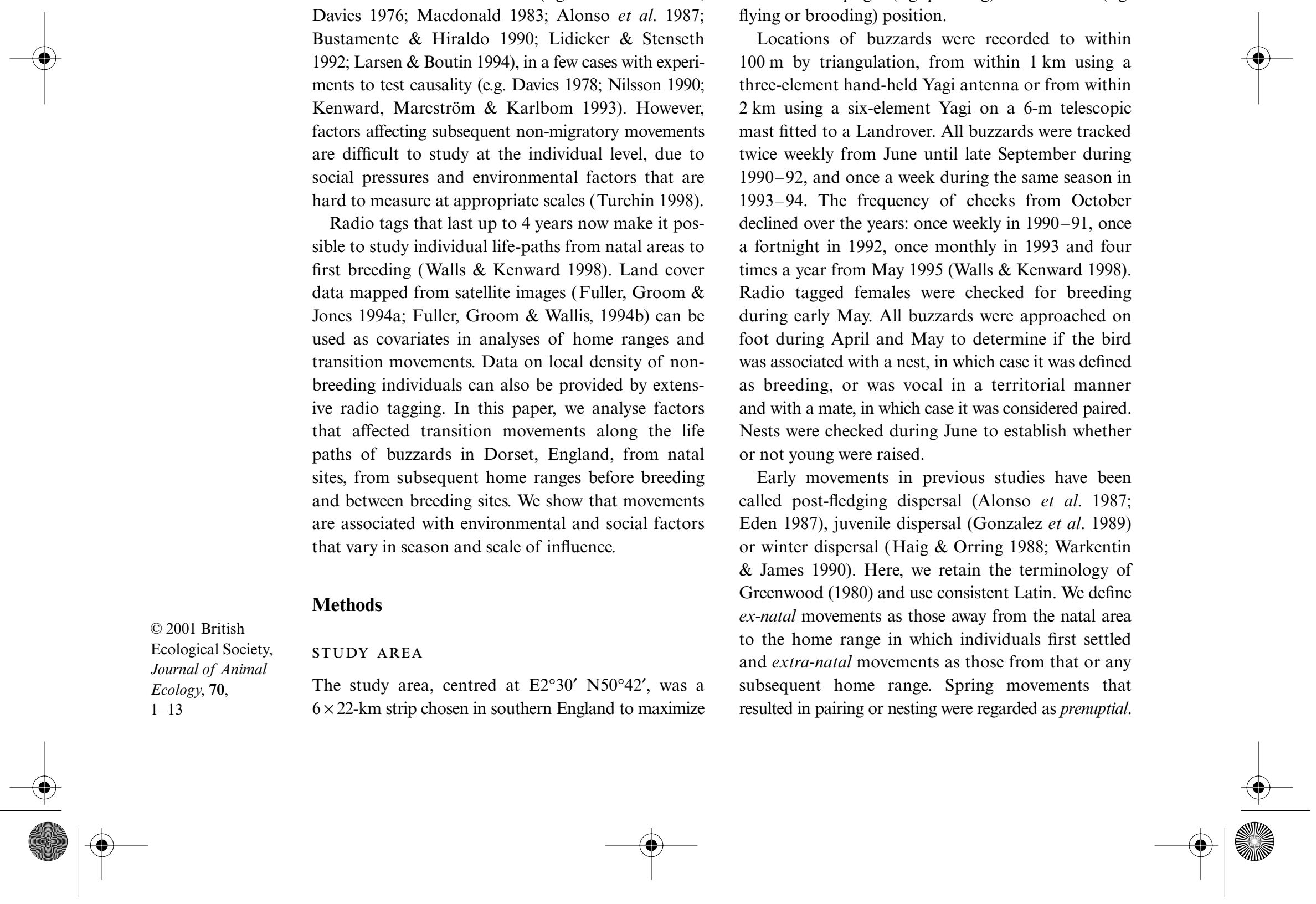
Life path analysis

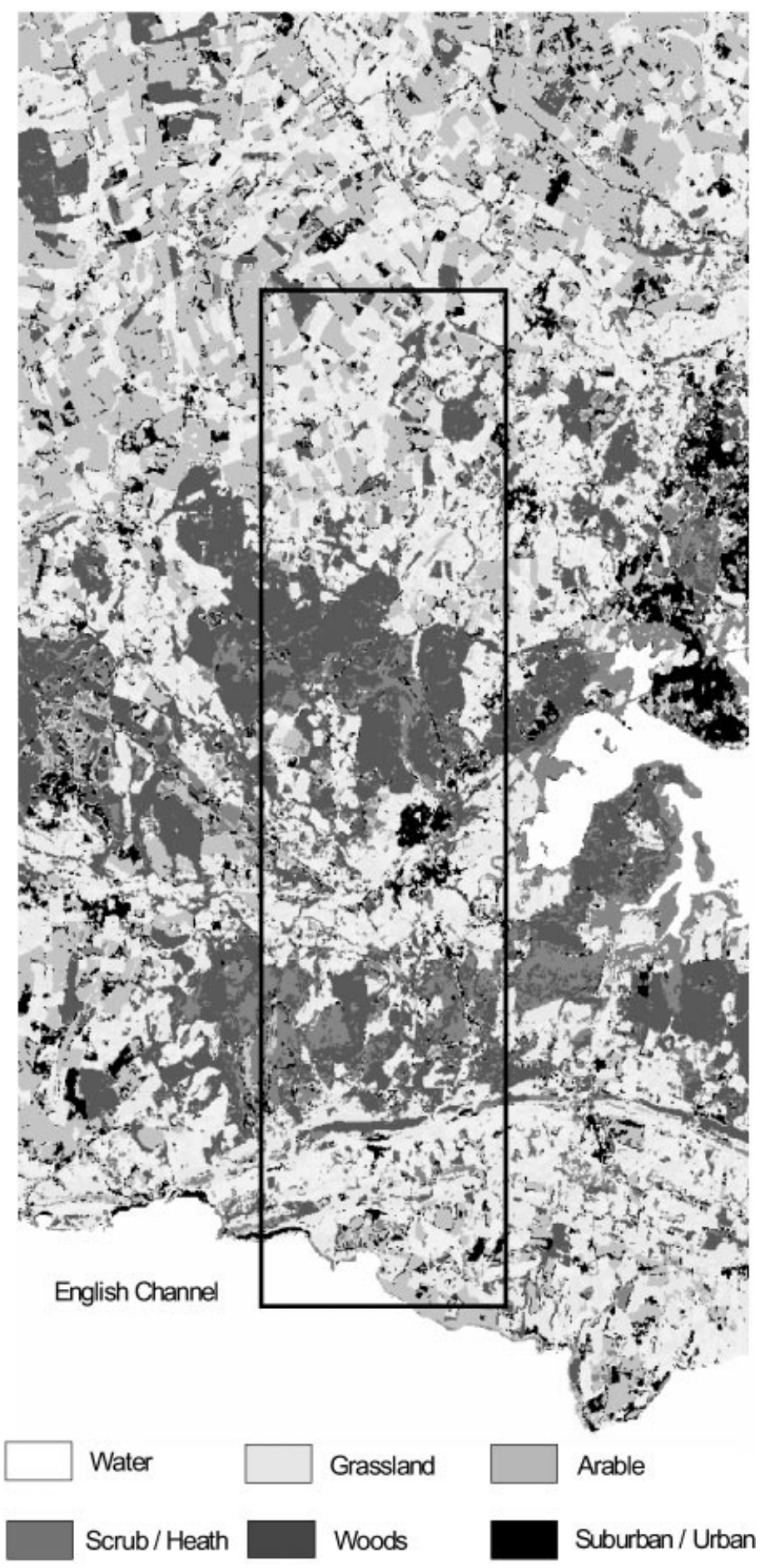

Fig. 1. Combinations of categories from the Land Cover Map of Great Britain around the $6 \times 22-\mathrm{km}$ study area (outlined) in which 144 buzzards were radio tagged during 1990-94.

Movements between nuptial sites, corresponding to the breeding dispersal of Greenwood (1980), were termed post-nuptial.

\section{DATA ANALYSES}

(C) 2001 British Ecological Society, Journal of Animal Ecology, 70, $1-13$
The detection of transition movements was hindered by excursions of up to $25 \mathrm{~km}$ from nests, which were common during the dispersal periods (Walls \& Kenward 1995). Ex-natal dispersal was defined when a buzzard went more than $1 \mathrm{~km}$ from its nest, which represented a statistical transition from a nest-centred distance distribution to a secondary distribution (Walls \& Kenward 1995), and did not return within 1 month; birds making excursions always returned within 2 days. The date of dispersal was estimated half-way between detection of dispersal and the last record within $1 \mathrm{~km}$ of its nest. Analyses of predispersal habitats and dispersal distances were based either on the natal nest or on focal points. On average, these

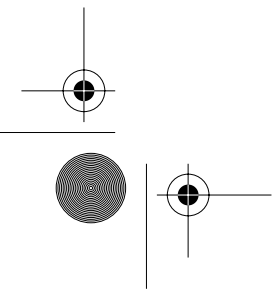


R.E. Kenward,

S.S. Walls \&

K.H. Hodder
(C) 2001 British Ecological Society, Journal of Animal Ecology, 70, $1-13$ focal points were estimated from seven locations (1-34) recorded during each season. If there were less than three locations, the focal point was the first record. Otherwise, we followed the rationale of Spencer \& Barrett (1984) for defining a range centre, as the location with the minimal mean inverse distance to the other locations (the harmonic mean). Division by zero for locations at the same co-ordinates was avoided by displacing such locations by one unit of the tracking resolution.

Nest-based estimates of ex-natal dispersal distances were measured from the nest to the focal point following the dispersal. Focal points were then used to identify extra-natal, prenuptial and post-nuptial movements. Distance records were thus based on the distance between single locations and were therefore comparable with ring recoveries. A transition movement was recorded if the distance between two subsequent focal points was more than $1 \mathrm{~km}$. This was the distance threshold for natal dispersal, and was also greater than the mean $690-\mathrm{m}(\mathrm{SE}=44)$ radius that resulted if standard 30-location convex polygon home ranges were treated as circles for 69 juvenile buzzards in winter.

Land cover data were primarily from the Land Cover Map of Great Britain (LCMGB), which has 25 land cover classes in 25-m rasters. The LCMGB is based on supervised likelihood classifications of combined scenes imaged by the Landsat Thematic Mapper in November 1989 and July 1990 (Fuller et al. $1994 a, b)$. The 25 classes were grouped into 16 categories chosen before the analyses (Appendix 1). Independent analyses indicate that the LCMGB is 79-84\% accurate (Fuller, Wyatt \& Barr 1998). Since grassland and arable areas could change appreciably between years, data were also recorded by field survey in a $1-\mathrm{km}$ radius around every nest each year. Soil data from the Soil Survey and Land Research Centre, Cranfield University, were combined into six main categories: calcareous, fine loam, coarse loam, sands, silts and clays.

Land cover and soils around nests were estimated in circular buffers with radii of $500 \mathrm{~m}, 1 \mathrm{~km}$ and $2 \mathrm{~km}$ using Ranges V software (Kenward \& Hodder 1996). Respectively, these scales corresponded to the zones used during post-nestling feather growth, during the whole post-nestling dependence period and double that radius (Tyack, Walls \& Kenward 1998). For land cover availability away from nests, we used buffer radii of $250 \mathrm{~m}, 500 \mathrm{~m}, 1 \mathrm{~km}$ and $2 \mathrm{~km}$ from buzzard focal points recorded during the autumn (August-October, excluding August for juveniles), winter (DecemberFebruary) and summer (April-July) periods. These buffers had areas of 20, 79, 314 and 1256 ha, respectively, which were appropriate for areas visited and visible to buzzards. Size estimates for the strongly mononuclear home ranges of buzzards in their first autumn averaged from 43 ha, for cores defined objectively by cluster analysis (Kenward et al., in press), up to 280 ha for ellipses (Jennrich \& Turner 1969) with $99 \%$ inclusion of the location density distribution.

Social variables were: (i) brood size at marking, (ii) number of siblings present when each bird dispersed (or at 1 October if there was no early dispersal); and the density of nests within (iii) $1 \mathrm{~km}$ and (iii) $2 \mathrm{~km}$ radii of the nest or focal point. Maps of spacing indices for nests and non-breeding buzzards were prepared as $500-\mathrm{m}$ rasters within a $1-\mathrm{km}$ boundary around the study area. Each raster was assigned the value of the harmonic mean distance from its centre to all nests or buzzard focal points. Calculations were in units of the raster resolution $(500 \mathrm{~m})$, with one unit used for any location less than $500 \mathrm{~m}$ from the raster's centre The spacing index for non-breeding buzzards used autumn focal points for all juveniles $(n=114)$ except the one nearest to the centre of each raster, and was thus exclusive of influence by the local bird. Spacing indices were then estimated within buffers centred on the focal point of each bird in each season by $\Sigma v_{i} \cdot a_{i} /$ $\Sigma a_{i}$, where $v_{i}$ was the harmonic mean spacing value of each raster and $a_{i}$ its area within the buffer. Spacing values in the $500-\mathrm{m}$ rasters varied from 1.35 to $2.5 \mathrm{~km}$ between nests and from 1.4 to $2.85 \mathrm{~km}$ between juvenile buzzards in autumn.

We used binary logistic regressions in Minitab 11 (Minitab Inc., 3081 Enterprise Drive, State College, PA 16801-3008, USA) to investigate whether or not buzzards moved from natal areas and subsequent ranges (James \& McCulloch 1990). Distances moved from nests or between focal points were normalized by $\log _{10}$ transformation (Walls \& Kenward 1995) before multiple regression analyses. In case independent variables such as spacing and brood sizes were influenced by land cover, regressions of movement variables on sociality variables were first run with land cover components forced to give them priority in regressions. Effects of soils were investigated by separate regressions, first with forcing of land cover priority and then with soil priority. In tests for effects of so many independent variables, there is a high risk of Type I errors (false positive). We therefore based our conclusions only on relationships significant at the $1 \%$ level (shown in bold and underlined in the tables) or which occurred in more than one period at the $5 \%$ level. Interaction effects were examined by repeating regressions with inclusion of interaction terms, which were created as products for all pairs of independents that were significant in initial models.

\section{Results}

\section{THE SEASONAL PATTERN OF MOVEMENTS}

Ex-natal movements by buzzards occurred primarily between August and October in their first autumn, and between February and June the following year. A few more birds moved between August and October in their second autumn (Fig. 2).

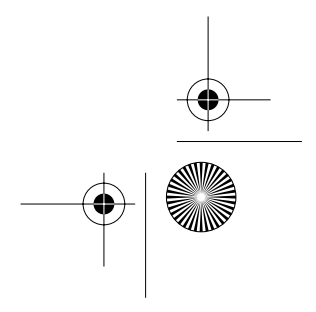


Life path analysis

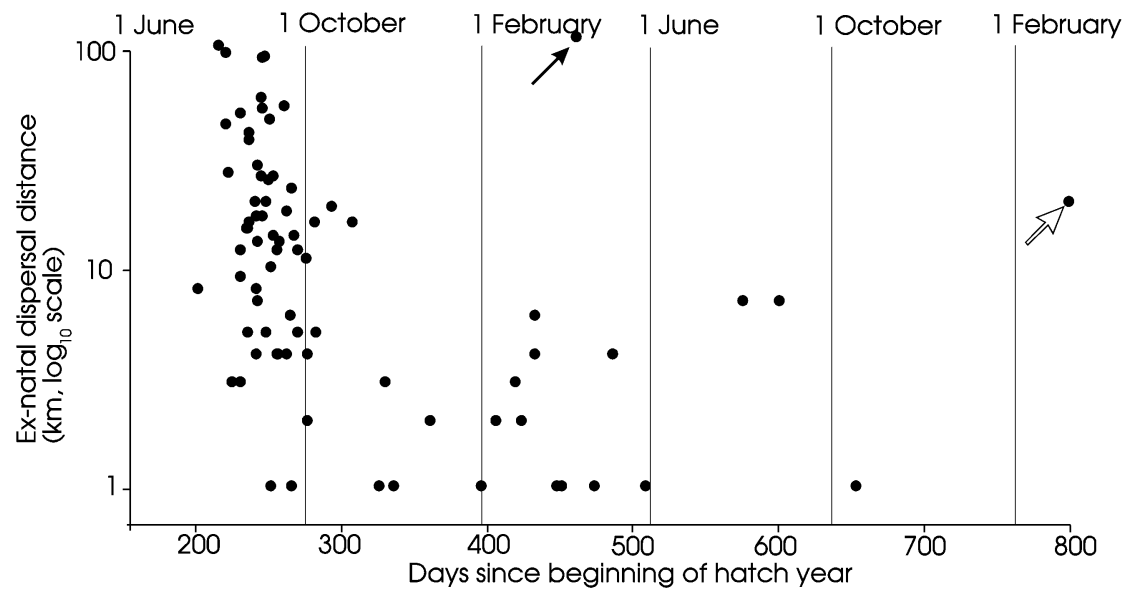

Fig. 2. Ex-natal dispersal distances of buzzards as a function of dispersal day. The solid arrow indicates the only buzzard that migrated between two sites after leaving its natal area in spring. The open arrow indicates a buzzard that bred in its second spring immediately after leaving its natal area.

Natal dispersal distances varied with season. As a whole, distances declined to the end of the first winter $\left(r_{69}=-0 \cdot 43, P<0 \cdot 001\right)$. However, this decline represented two periods. Most of the buzzards left in the August-September period, during which there was no significant change in distance moved with date or with age of bird $\left(r_{53} \leq-0 \cdot 16, P>0 \cdot 2\right)$. There was no significant tendency for distance travelled to increase again from February in the first winter $(P=0 \cdot 08)$.

In view of the seasonal changes in behaviour, analyses were separated for movements: (i) during the buzzards' first summer-autumn period of AugustSeptember; (ii) during the autumn-winter period of October-January; and (iii) during the following wintersummer period of February-June. Ex-natal and extranatal movements were considered in turn within each season, first to detect factors that affected whether a bird dispersed and then how far it moved. Nuptial movements occurred after ex-natal dispersal had finished and are therefore considered separately at the end.

\section{JUVENILE MOVEMENTS: SUMMER-AUTUMN}

The number of siblings present with each buzzard was the most important factor determining whether it would leave its natal area in the first autumn (Table 1, Fig. 3). In general, only one young buzzard stayed near its nest through the winter. The birds were most likely to leave at this stage: (i) if they had an increasing number of siblings present; (ii) if there was little coarse loam soil within $2 \mathrm{~km}$ of the nest and (at the $5 \%$ level); (iii) if there was much developed land within the $1-\mathrm{km}$ nest buffer (Table 1). Brood size had no effect on whether they left, either as a fourth factor in logistic regression $(z=-1 \cdot 33)$, or when divided into categories of 0,1 and 2 siblings (trend test from Maxwell 1961: 63, $\chi_{1}^{2}=1 \cdot 60$ ) or when included in interaction terms.

However, for the 51 birds that left before October, the dispersal distance was most strongly related to brood size (Pearson $r_{49}=-0 \cdot 34, P=0 \cdot 01$ ). The only improvement significant at the $1 \%$ level was inclusion of short grass within $500 \mathrm{~m}$ of the nest $\left(F_{1 / 48}=10 \cdot 4\right.$, $P<0 \cdot 005)$. However, a model with three further variables at $5 \%$ (Table 2) explained $46 \%$ of the variation in distance travelled $(P<0 \cdot 001)$, through including the presence of grass heathland in the $1 / 2-\mathrm{km}$ buffer $\left(F_{1 / 47}=7 \cdot 0, P<0.02\right)$ and presence of siblings together with absence of conifer woodland in the $1-\mathrm{km}$ buffer $\left(F_{2 / 45}=3 \cdot 4, P<0 \cdot 05\right)$. Long dispersal distances were associated mainly with coming from a small brood and having little short grass, but also with leaving early from large broods, and having little coniferous woodland or much grassy heathland nearby. The distance travelled was most strongly associated with factors scaled close to the nest.

\section{JUVENILE MOVEMENTS: AUTUMN-WINTER}

The tendency for ex-natal movements during OctoberJanuary was related to several habitat variables. The strongest bivariate relationship was with shrubheathland in the $2-\mathrm{km}$ nest buffer (Table 1). However, there were strong negative correlations between heathland and arable land in the LCMGB estimates (Table 3). The best multivariate models excluded heathland in favour of arable land. The tendency to move was classified $88 \%$ correctly $(G=28 \cdot 3$, d.f. $=4$, $P<0.001)$ by a combination of arable land in the 2$\mathrm{km}$ buffer, presence of siblings, short-grassland and (at the $5 \%$ level) long grass within $500 \mathrm{~m}$ of the nest (Table 1). There was $97 \%$ concordance $(G=42 \cdot 7$, d.f. $=4, P<0.001)$ if the same relationship was based on arable land recorded each year within $1 \mathrm{~km}$ of nests by field survey. At this stage, buzzards left if they had many sibs still present and there was little arable land around the nest, especially if there was little short grass close to the nest.

Among the 15 birds that left, distances travelled increased with lack of arable land in the 2-km nest buffer $\left(r_{13}=-0.66, P<0 \cdot 01\right)$, and lack of conifer
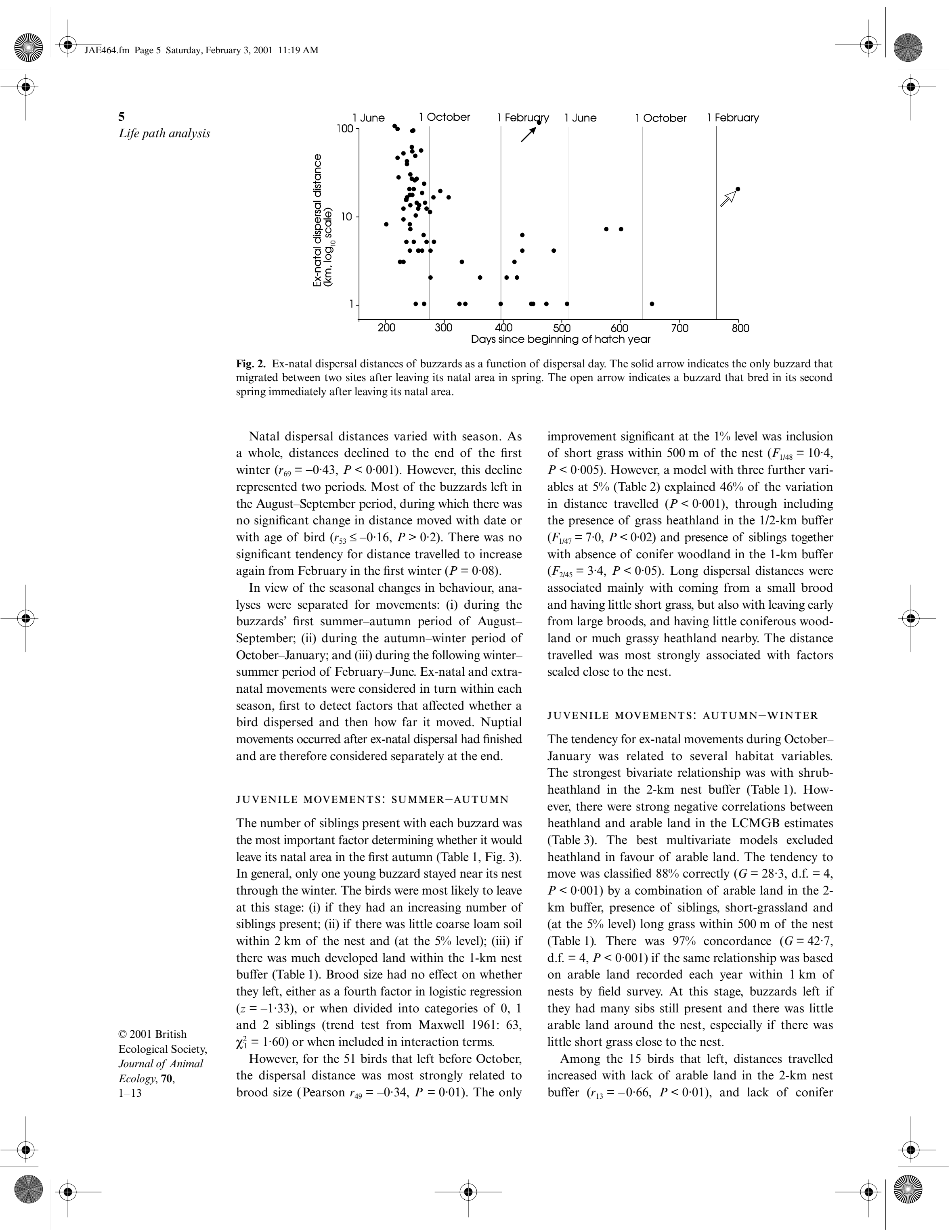
Table 1. Sample sizes, mean distances (top) and $z$-statistics from binary logistic regressions of the tendency of buzzards to make natal and extra-natal movements on variables that were significant (bold ${ }^{* * *}$ shows $P<0.01$ and italic $^{* * *} P<0.001$ ) in one or more univariate (middle) or multivariate model (bottom); signs shows the direction of any correlation. The sample available for extra-natal movements in autumn ( $\dagger$ ) was of birds that had dispersed in summer $(\dagger)$, whereas the sample in winter $(+\$)$ was a combination of early and late dispersers $(\$)$. No data on social factors were available away from the study area

\begin{tabular}{|c|c|c|c|c|c|c|c|c|}
\hline \multirow{3}{*}{$\begin{array}{l}\text { Season } \\
\text { Movement } \\
\text { Analysis }\end{array}$} & & \multirow{3}{*}{$\begin{array}{l}\text { Summer } \\
\text { Ex-natal } \\
\text { Nest }\end{array}$} & \multicolumn{3}{|l|}{ Autumn } & \multicolumn{3}{|l|}{ Winter } \\
\hline & & & \multicolumn{2}{|l|}{ Ex-natal } & \multirow[b]{2}{*}{$\begin{array}{l}\text { Extra-natal } \\
\text { Focal }\end{array}$} & \multicolumn{2}{|l|}{ Ex-natal } & \multirow[b]{2}{*}{$\begin{array}{l}\text { Extra-natal } \\
\text { Focal }\end{array}$} \\
\hline & & & Nest & Focal & & Nest & Focal & \\
\hline \multicolumn{2}{|l|}{ Tracked at start } & 146 & 63 & 63 & $51 \dagger$ & 40 & 40 & $56 \% t$ \\
\hline \multicolumn{2}{|l|}{ Dead or lost } & 32 & 8 & 8 & 10 & 7 & 7 & 9 \\
\hline \multicolumn{2}{|l|}{ Number dispersed } & $51 \dagger$ & 15 & $15 \$$ & $15 \$$ & 15 & 15 & 20 \\
\hline \multicolumn{2}{|l|}{ Number stayed } & 63 & 40 & 40 & $26 \%$ & 18 & 18 & 27 \\
\hline \multicolumn{2}{|l|}{ Geometric mean } & $16 \cdot 2$ & $5 \cdot 3$ & $3 \cdot 6$ & 8 & $4 \cdot 3$ & $2 \cdot 9$ & $9 \cdot 3$ \\
\hline \multicolumn{2}{|l|}{ Distance km $(95 \% \mathrm{CL})$} & $(12 \cdot 2-21 \cdot 4)$ & $(3 \cdot 3-8 \cdot 4)$ & $(0 \cdot 5-6 \cdot 7)$ & $(0 \cdot 2-13)$ & $(2 \cdot 5-7 \cdot 6)$ & $(0 \cdot 5-4 \cdot 0)$ & $(0 \cdot 2-16 \cdot 0)$ \\
\hline \multicolumn{9}{|c|}{ Univariate binary logistic regression } \\
\hline \multicolumn{9}{|l|}{ Demographic } \\
\hline Number of siblings & (Sibs) & $\underline{3 \cdot 25^{* *}}$ & 1.94 & No data & No data & $0 \cdot 25$ & No data & No data \\
\hline Nest spacing $250 \mathrm{~m}$ & $\left(\mathrm{Nest}^{1} / 4\right)$ & $\overline{1 \cdot 50}$ & $1 \cdot 03$ & $0 \cdot 10$ & No data & $-1 \cdot 52$ & $-0 \cdot 34$ & No data \\
\hline Non-breeder index 500 & $\left(\mathrm{NBI}^{1} / 2\right)$ & $0 \cdot 90$ & $1 \cdot 57$ & $1 \cdot 03$ & No data & $-1 \cdot 12$ & $-0 \cdot 81$ & No data \\
\hline \multicolumn{9}{|l|}{ Land covers } \\
\hline Arable $500 \mathrm{~m}$ & $\left(\mathrm{Arbl}^{1}{ }_{2}\right)$ & $-0 \cdot 50$ & -1.69 & $-1 \cdot 59$ & $-0 \cdot 89$ & $0 \cdot 70$ & $1 \cdot 07$ & $2 \cdot 00^{*}$ \\
\hline Arable $1 \mathrm{~km}$ & (Arbl1) & $-0 \cdot 20$ & $-2 \cdot 00^{*}$ & $-1.93 *$ & $-1 \cdot 10$ & $0 \cdot 34$ & $1 \cdot 12$ & $1 \cdot 76$ \\
\hline Arable $2 \mathrm{~km}$ & (Arbl2) & $0 \cdot 65$ & $-2 \cdot 29 *$ & $-2 \cdot 44^{*}$ & $-0 \cdot 90$ & $-0 \cdot 12$ & $0 \cdot 58$ & $0 \cdot 78$ \\
\hline Short grass $500 \mathrm{~m}$ & $\left(\operatorname{ShoG}^{1} / 2\right)$ & -0.65 & $-1 \cdot 57$ & -1.71 & $-0 \cdot 21$ & $-1 \cdot 23$ & $-1 \cdot 05$ & $-0 \cdot 19$ \\
\hline Short grass $1 \mathrm{~km}$ & (ShoG1) & $-0 \cdot 51$ & $-2 \cdot 30^{*}$ & $-2 \cdot 13^{*}$ & $0 \cdot 70$ & $-0 \cdot 48$ & $-0 \cdot 39$ & $-1 \cdot 11$ \\
\hline Short grass $2 \mathrm{~km}$ & (ShoG2) & $-0 \cdot 74$ & $-0 \cdot 49$ & $-1 \cdot 04$ & $1 \cdot 03$ & $-0 \cdot 70$ & $-0 \cdot 60$ & $-1 \cdot 70$ \\
\hline Long grass $500 \mathrm{~m}$ & $\left(\operatorname{LonG}^{1} / 2\right)$ & $1 \cdot 84$ & $0 \cdot 64$ & $-1 \cdot 00$ & $0 \cdot 74$ & $-1 \cdot 90$ & $-1 \cdot 10$ & -1.68 \\
\hline Long grass $1 \mathrm{~km}$ & (LonG1) & $0 \cdot 97$ & $-0 \cdot 87$ & $-0 \cdot 80$ & $0 \cdot 57$ & $-1 \cdot 63$ & $-1 \cdot 51$ & $-2 \cdot 39^{*}$ \\
\hline Long grass $2 \mathrm{~km}$ & (LonG2) & $0 \cdot 31$ & $-0 \cdot 81$ & $-1 \cdot 14$ & $1 \cdot 42$ & $-1 \cdot 27$ & $-1 \cdot 54$ & $-1 \cdot 87$ \\
\hline Grass heath $1 \mathrm{~km}$ & (GrHe1) & $-0 \cdot 36$ & $2 \cdot 23^{*}$ & $2 \cdot 34^{*}$ & $1 \cdot 00$ & $0 \cdot 29$ & $0 \cdot 80$ & $0 \cdot 87$ \\
\hline Grass heath $2 \mathrm{~km}$ & (GrHe2) & $0 \cdot 33$ & $2 \cdot 66^{*}$ & $2 \cdot 47 *$ & $1 \cdot 15$ & $0 \cdot 88$ & $0 \cdot 75$ & $0 \cdot 92$ \\
\hline Shrub heath $1 \mathrm{~km}$ & $(\mathrm{ShHe1})$ & $-0 \cdot 15$ & $2 \cdot 51^{*}$ & $2 \cdot 34 *$ & $1 \cdot 18$ & $0 \cdot 59$ & $0 \cdot 20$ & $0 \cdot 47$ \\
\hline Shrub heath $2 \mathrm{~km}$ & $(\mathrm{ShHe} 2)$ & $-0 \cdot 17$ & $\underline{2 \cdot 93 * *}$ & $2 \cdot 49^{*}$ & $0 \cdot 67$ & $0 \cdot 76$ & $0 \cdot 20$ & $0 \cdot 75$ \\
\hline Scrub 1 km & (Scrub1) & -0.08 & 0.62 & $0 \cdot 25$ & $-0 \cdot 85$ & $1 \cdot 03$ & $0 \cdot 50$ & $-1 \cdot 45$ \\
\hline Deciduous $2 \mathrm{~km}$ & (Deci2) & $-1 \cdot 23$ & $1.98^{*}$ & $1 \cdot 28$ & $-0 \cdot 77$ & $0 \cdot 82$ & $0 \cdot 06$ & $1 \cdot 26$ \\
\hline Conifer $2 \mathrm{~km}$ & (Coni2) & $-0 \cdot 82$ & $0 \cdot 24$ & $1 \cdot 48$ & $-1 \cdot 17$ & $1 \cdot 16$ & $0 \cdot 86$ & $1 \cdot 17$ \\
\hline Buildings $1 \mathrm{~km}$ & (Build1) & $1 \cdot 82$ & $1 \cdot 75$ & $-0 \cdot 75$ & $-0 \cdot 10$ & $-0 \cdot 98$ & $0 \cdot 18$ & $-1 \cdot 52$ \\
\hline \multicolumn{9}{|l|}{ Soil } \\
\hline Fine loam $1 \mathrm{~km}$ & (FineLo1) & $-0 \cdot 16$ & $-2 \cdot 72 *$ & $-2 \cdot 82 * *$ & $-0 \cdot 05$ & $-1.97 *$ & $-2 \cdot 19^{*}$ & $0 \cdot 30$ \\
\hline Coarse loam $2 \mathrm{~km}$ & (CoLo2) & $-2 \cdot 19^{*}$ & $-0 \cdot 52$ & $-0 \cdot 06$ & -0.02 & $-0 \cdot 21$ & $1 \cdot 02$ & $0 \cdot 44$ \\
\hline Distance from nest & (Dist) & - & - & $1 \cdot 84$ & -1.09 & - & $-0 \cdot 25$ & $1 \cdot 35$ \\
\hline \multirow{3}{*}{\multicolumn{2}{|c|}{ Multivariate logistic regression }} & $\begin{array}{l}\text { Sibs } \\
\text { CoLo2 }\end{array}$ & $\begin{array}{ll}\text { Arbl2 } & \mathbf{- 3 \cdot 2} \\
\text { Sibs } & \mathbf{+ 2 \cdot 9}\end{array}$ & $\begin{array}{ll}\text { Arbl2 } & -2.35 \\
\text { ShoG1 } & -2.09\end{array}$ & $\begin{array}{l}\mathrm{NBI}^{1} / 2 \\
\text { FineLo }\end{array}$ & $1 \frac{-\mathbf{2 \cdot 6}}{-2 \cdot 4}$ & $\begin{array}{ll}\text { FineLol } & \mathbf{- 2 \cdot 7 2} \\
\mathrm{NBI}^{1} / 2 & -1 \cdot 96\end{array}$ & $\begin{array}{l}\operatorname{Arbl}_{1}^{1}{ }_{2}^{2} \\
\text { Conit } 2^{+2 \cdot 56}\end{array}$ \\
\hline & & Build $1 \overline{+2 \cdot 3}$ & $\mathrm{ShoG}^{1} / 2 \quad \overline{\mathbf{- 2 \cdot 7}}$ & & Scrub1 & $+2 \cdot 3$ & & \\
\hline & & & $\operatorname{LonG}^{1} / 2+2 \cdot 2$ & & & & & \\
\hline \multirow{2}{*}{\multicolumn{2}{|c|}{$\begin{array}{l}\text { G } \\
\text { Overall P }\end{array}$}} & $24 \cdot 3$ & $28 \cdot 3$ & $12 \cdot 9$ & \multicolumn{2}{|c|}{$21 \cdot 3$} & $11 \cdot 6$ & $9 \cdot 3$ \\
\hline & & $<0.001$ & $<0.001$ & $=0.002$ & \multicolumn{2}{|c|}{$=0.001$} & $=0.003$ & $=0.01$ \\
\hline
\end{tabular}

(C) 2001 British

Ecological Society, Journal of Animal Ecology, 70, $1-13$ woodland within $1 \mathrm{~km}$ of the nest $\left(F_{1 / 12}=5 \cdot 9, P<0 \cdot 05\right)$. The arable land recorded annually within $1-\mathrm{km}$ buffers was more strongly correlated with these distances $\left(r_{13}=-0 \cdot 77\right)$ than the LCMGB data $\left(F_{1 / 12}=4 \cdot 7\right.$, $P=0 \cdot 05)$. A combination of this variable with conifer woodland explained $71 \%$ of the variation in distances travelled $(P<0.001)$ : the distance was affected by habitats at the larger scales. These 15 buzzards settled after travelling only one-third of the distance (Fig. 2) moved by the 51 that left before October $\left(t_{64}=4 \cdot 44\right.$, $P<0.001)$. There was also a weak tendency for female buzzards to travel further than males from the nest, both in October-January $\left(t_{13}=2 \cdot 61, P=0.02\right)$ and August-September $\left(t_{49}=2 \cdot 23, P=0 \cdot 03\right)$. However, links with sex were excluded by more significant variables in multivariate models and were found in no further analyses.

Analyses of ex-natal movements gave similar results using focal points instead of nests. Ex-natal dispersal was most likely with much shrubby-heathland, especially in the $2-\mathrm{km}$ buffer $(G=7 \cdot 4$, d.f. $=1, P=0 \cdot 007)$. As for nest-based analyses, additional variables did not improve this relationship significantly, and a combination of less arable (within $2 \mathrm{~km}$ ) and less short grass $(1 \mathrm{~km})$ gave the strongest prediction of ex-natal dispersal (Table 1).

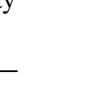


Life path analysis
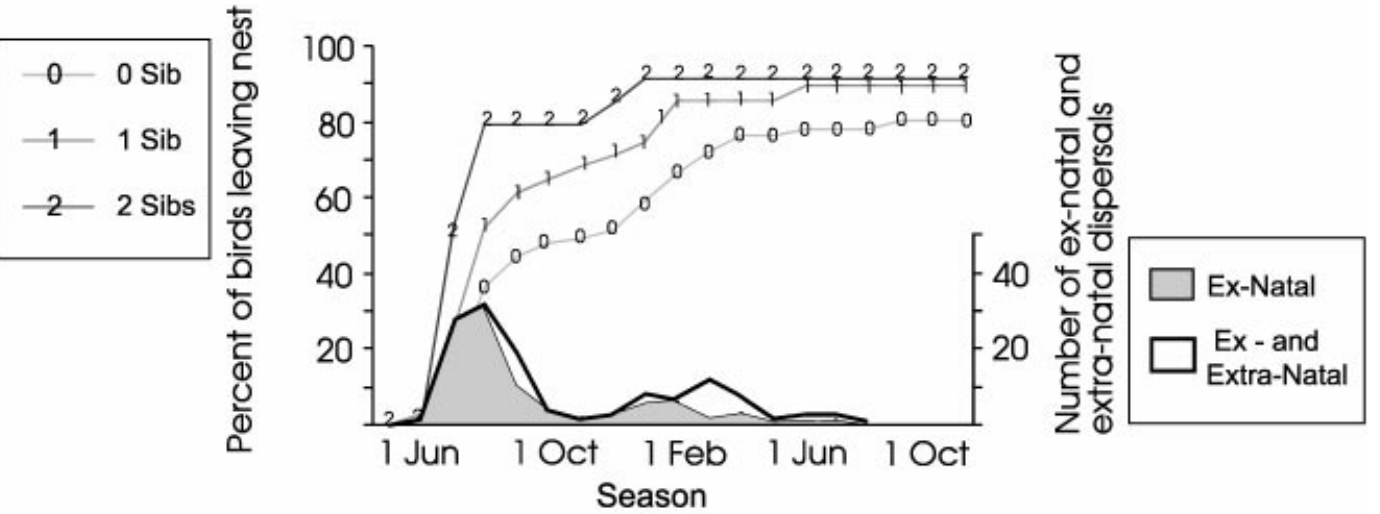

Fig. 3. The extent of ex-natal and extra-natal dispersal of buzzards as a function of time. Lines with numbers show the cumulative percentage that left when there were 2, 1 and 0 siblings remaining with them at the natal nest. The number of buzzards that made ex-natal dispersal movements is shown by the shaded area, with extra-natal movements included under the thick line.

Table 2. The variables associated with whether ex-natal or extra-natal movement occurred, and the distances travelled by buzzards of different ages. Values are the scale in kilometres at which the effect was most significant (bold** shows $P<0 \cdot 01$ and italic $\left.^{* * *} P<0 \cdot 001\right)$

\begin{tabular}{|c|c|c|c|c|c|c|}
\hline & \multirow{2}{*}{$\begin{array}{l}\text { Summer } \\
\text { Ex-natal }\end{array}$} & \multicolumn{2}{|l|}{ Autumn } & \multicolumn{2}{|l|}{ Winter } & \multirow{2}{*}{$\begin{array}{l}\text { 2nd Year } \\
\text { Extra-nata }\end{array}$} \\
\hline & & Ex-natal & Extra-natal & Ex-natal & Extra-natal & \\
\hline \multirow[t]{2}{*}{ Number of siblings } & Move? & $\underline{+* * *}$ & $\underline{+* *}$ & & & \\
\hline & Distance & $+*$ & & & & \\
\hline \multirow[t]{2}{*}{ Distance from nest } & Move? & & & & & \\
\hline & Distance & & & & $+* *$ & \\
\hline \multirow[t]{2}{*}{ Non-breeder density } & Move? & & & $+1 / 2 * *$ & & \\
\hline & Distance & & & & & \\
\hline \multirow{2}{*}{ Grass heath } & Move? & & & & & \\
\hline & Distance & $+1 / 2 *$ & & $+2 * * *$ & $+1 / 2 *$ & \\
\hline \multirow[t]{2}{*}{ Long grass } & Move? & & $+1 / 2 *$ & & & $+2 * *$ \\
\hline & Distance & & & $+1 / 2^{* *}$ & & \\
\hline \multirow[t]{2}{*}{ Scrub } & Move? & & & $+1^{*}$ & & \\
\hline & Distance & & & & & $-1^{*}$ \\
\hline \multirow[t]{2}{*}{ Conifer } & Move? & & & & $+2 *$ & \\
\hline & Distance & $-1^{*}$ & $-1^{*}$ & & & \\
\hline \multirow[t]{2}{*}{ Arable } & Move? & & $-2 * *$ & & $+1 / 2 * *$ & \\
\hline & Distance & & $-2^{* *}$ & & $\frac{2}{+1 / 2^{* *}}$ & \\
\hline \multirow[t]{2}{*}{ Short grass } & Move? & & $-1 / 2^{* * *}$ & & & $-2 * *$ \\
\hline & Distance & $-{ }^{1} / 2 * * *$ & & & & \\
\hline \multirow[t]{2}{*}{ Loam } & Move? & $-2^{* * *}$ & & $-1^{*}$ & & \\
\hline & Distance & & & & & \\
\hline \multirow[t]{2}{*}{ Brood size } & Move? & & & & & \\
\hline & Distance & _*** & & & & \\
\hline
\end{tabular}

Table 3. Pearson correlation coefficients for autumn density of non-breeding buzzards $(\mathrm{NBI} 1 / 2)$ and habitat variables that associated strongly with dispersal movements (see Table 1 for definitions), across 47 nest sites. Bold shows $P<0 \cdot 01$ and italic $P<0 \cdot 001$. Nest density correlated strongly with $\mathrm{NBI}^{1} / 2(r=\mathbf{0} \cdot \mathbf{8 2})$, and deciduous woodland with conifers $(r=\mathbf{0} \cdot 67)$. There were no significant relationships of brood size, sibling number at dispersal or sex with habitats

\begin{tabular}{|c|c|c|c|c|c|c|c|c|c|c|}
\hline & $\mathrm{NBI}^{1} / 2$ & $\operatorname{LonG}^{1} / 2$ & $\mathrm{ShoG}^{1} / 2$ & $\mathrm{Arbl}^{1} / 2$ & Arbl2 & Coni2 & ShHe2 & GrHe2 & Scrub1 & Build1 \\
\hline FineLo1 & $0 \cdot 012$ & $0 \cdot 164$ & $0 \cdot 058$ & -_0.051 & -0.056 & $-0 \cdot 116$ & $0 \cdot 045$ & -0.009 & $0 \cdot 105$ & $\underline{0.376}$ \\
\hline Build1 & $0 \cdot 124$ & $0 \cdot 281$ & -0.010 & $\underline{0.440}$ & $0 \cdot 348$ & -0.339 & $-0 \cdot 181$ & -0.231 & $-0 \cdot 244$ & \\
\hline Scrub1 & -0.664 & $0 \cdot 224$ & -0.008 & $-\overline{0.329}$ & -0.458 & -0.089 & 0.058 & $\underline{0.399}$ & & \\
\hline GrHe2 & -0.549 & $-0 \cdot 167$ & $-0 \cdot 200$ & -0.423 & $-0 \cdot 773$ & $\underline{0.392}$ & 0.862 & & & \\
\hline ShHe2 & $-0 \cdot 330$ & $-0 \cdot 376$ & $-0 \cdot 220$ & $\overline{-0 \cdot 384}$ & -0.743 & $\underline{0.470}$ & & & & \\
\hline Coni2 & 0.085 & -0.490 & $-0 \cdot 228$ & $\overline{-0 \cdot 273}$ & -0.373 & & & & & \\
\hline Arbl2 & $\underline{0.686}$ & $\overline{-0 \cdot 167}$ & $0 \cdot 035$ & $\underline{0.595}$ & & & & & & \\
\hline $\mathrm{Arbl}^{1} / 2$ & $\underline{0.500}$ & $-0 \cdot 217$ & $-0 \cdot 238$ & & & & & & & \\
\hline $\mathrm{ShoG}^{1} / 2$ & $\overline{0 \cdot 073}$ & $-0 \cdot 319$ & & & & & & & & \\
\hline LonG $^{1} / 2$ & $-0 \cdot 30$ & & & & & & & & & \\
\hline
\end{tabular}

(C) 2001 British Ecological Society, Journal of Animal Ecology, 70, 1-13

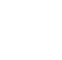


R.E. Kenward,

S.S. Walls \&

K.H. Hodder

C) 2001 British

Ecological Society, Journal of Animal

Ecology, 70,

$1-13$
A separate analysis, for 41 juveniles that had already settled in home ranges away from their natal area for the autumn-winter period, gave very different results. Neither the tendency of these birds to make an extra-natal movement, nor the distance travelled by the 15 dispersers, was linked significantly to sex or to any of the land cover variables measured, either singly or in combination (Tables 1 and 2).

\section{JUVENILE MOVEMENTS: WINTER-SUMMER}

A further 15 of 33 birds that remained near nests in January had left by the following July. The tendency to leave was negatively correlated with fine loam soil within $1 \mathrm{~km}$ of nests $(G=4.5$, d.f. $=1, P=0.035)$. The regression was improved by adding either the nest spacing in the 250 -mfocal buffer $(G=10 \cdot 7$, d.f. $=2$, $P=0 \cdot 005)$ or the juvenile buzzard spacing in the 500$\mathrm{m}$ nest buffer $(G=10 \cdot 6$, d.f. $=2, P=0 \cdot 005$, Table 1$)$. In both cases there was the same improvement by adding presence of scrub in the $1-\mathrm{km}$ buffer as a third variable $(G=21 \cdot 0$, d.f. $=3, P<0 \cdot 001)$. Movements were most likely in the absence of fine loam soil, where density of non-breeding buzzards was high close to the focal point and where there was much scrub.

Focal-point analyses confirmed that shortage of fine loam within $1 \mathrm{~km}$ was the most significant factor affecting ex-natal movements $(G=6 \cdot 0$, d.f. $=1, P=0 \cdot 014)$. Increasing non-breeder density added significantly to this at the $5 \%$ level, but not scrub (Table 1).

The 15 ex-natal dispersers travelled farther from nests that had much grassy heathland within $2 \mathrm{~km}$ $\left(r_{13}=+0.62, P<0.02\right)$. This relationship was improved $\left(F_{1 / 12}=11 \cdot 1, P<0 \cdot 01\right)$ if there was also much long grass within $500 \mathrm{~m}\left(r_{12}=+0 \cdot 82, P<0 \cdot 001\right)$. These movements were affected by habitat at the small scale, but only after controlling for the influence of grass heathland at a larger habitat scale.

Two land covers were associated with whether buzzards made extra-natal movements in spring. Too little long grass within $1 \mathrm{~km}(G=6 \cdot 9$, d.f. $=1$, $P=0.008)$ was associated with increased likelihood of leaving, but this effect disappeared in multivariate analyses. Those with most arable land within $500 \mathrm{~m}$ were also most likely to leave $(G=4 \cdot 4$, d.f. $=2$, $P=0.035)$ and this variable, combined with presence of coniferous woodland within $2 \mathrm{~km}$, gave the strongest multivariate correlation (Table 1).

Increase in distance travelled by 20 extra-natal movers was most strongly associated with presence of arable land in the 500-m buffer around their focal point $\left(r_{18}=+0 \cdot 74, n=20, P<0 \cdot 001\right)$. Distance from the natal nest also influenced how far a buzzard moved $\left(r_{18}=+0.52, P=0.019\right)$. Adding this variable improved the regression model $\left(F_{1 / 17}=9.9, P=0.006\right)$, which then explained $71 \%$ of variation in distance moved. Buzzards with most arable land close to their focal points travelled farthest, and especially those far from their natal nests (Fig. 4).

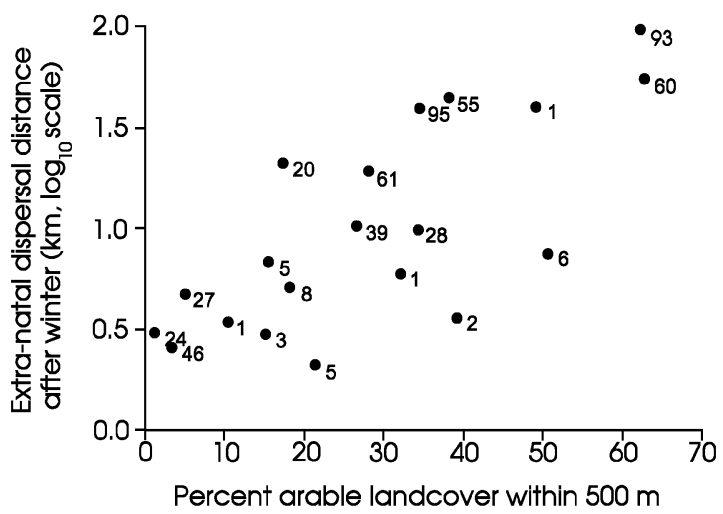

Fig. 4. The distance of extra-natal movements in spring as a function of arable land cover within $500 \mathrm{~m}$ of each buzzard's focal point ( $x$-axis) and distance from nests before the movements (suffixes).

\section{SECOND-YEAR MOVEMENTS}

Only one of 13 buzzards that remained near nata nests until the following summer left during the following autumn. However, among 52 other buzzards there were 18 extra-natal movements by birds that had relatively little short grass within $2 \mathrm{~km}$ of their focal points $(G=7 \cdot 6$, d.f. $=1, P<0.01)$ and especially if they also had much long grass within $2 \mathrm{~km}$ ( $G=16 \cdot 2$, d.f. $=2, \quad P<0 \cdot 001)$. Their tendency to move was therefore influenced by land cover on our largest scale.

After leaving, the distance travelled was greatest if there had been much grassy heathland within $500 \mathrm{~m}$ of their focal points $\left(r_{16}=+0.52, P=0.02\right)$, and especially if there had also been little scrub within $1 \mathrm{~km}\left(F_{1 / 15}=7 \cdot 3, P<0 \cdot 02\right)$. However, the relationship with grassy heathland was mainly due to only two birds that travelled long distances, and no relationship reached significance at the $1 \%$ level. Later in the second year, few buzzards were tracked in areas with buzzard spacing and soil data, few moved from their home ranges and there were no strong relationships with land cover.

During the second year a bias developed in the direction of buzzard movements. Focal points became significantly more to the east than the west of natal nests (sign test, $\mathrm{z}=2 \cdot 23, P=0 \cdot 006$ ). The buzzards $>20 \mathrm{~km}$ from their natal nests were most likely to be recorded in the east (Fig. 5).

\section{PRE-NUPTIAL MOVEMENTS}

No buzzards were recorded paired in their first year. Distances moved subsequently from winter focal points before pairing or breeding were short, with medians of $0.7 \mathrm{~km}$ (range: $0.01-20.7$ ) and $0.9 \mathrm{~km}$ (range: $0 \cdot 05-20 \cdot 7$ ), respectively (Fig. 6). Distances of these prenuptial movements did not differ from other extra-natal movements in the second year

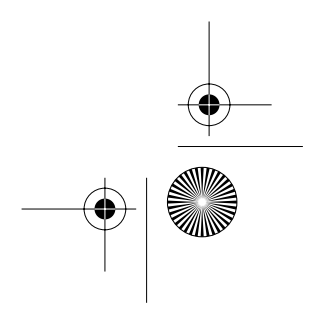


9 Life path analysis

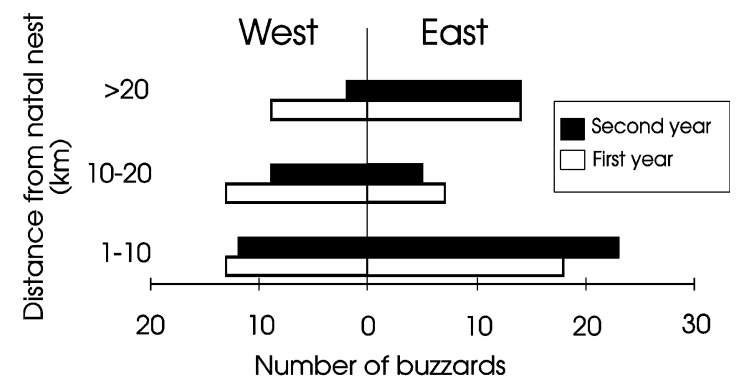

Fig. 5. Numbers of buzzards dispersing to the east or west in their first and second year of life, in three distance categories.

(a) 25

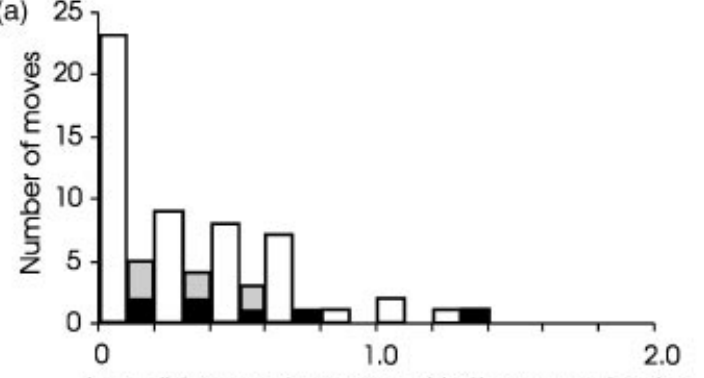

$\log _{10}$ distance of movement in the second spring

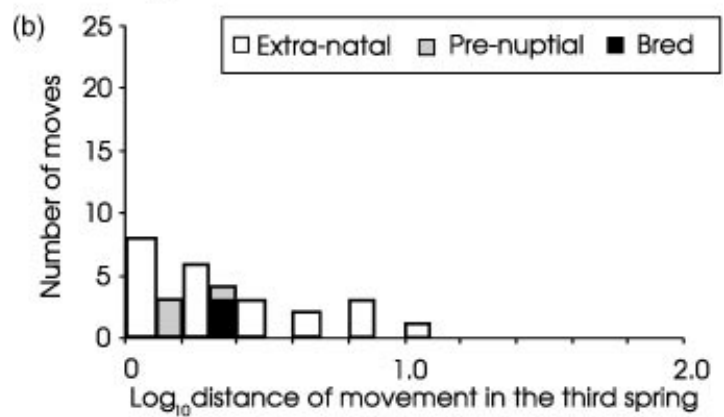

Fig. 6. The distance of extra-natal and prenuptial movements of buzzards in (a) their second, and (b) their third years.

$\left(t_{22}=-0 \cdot 26, P>0 \cdot 1\right)$, but they were significantly smaller in the third year $\left(t_{27}=2.81, P<0.01\right)$. Buzzards did not make large movements to breed, except for the one buzzard whose $21-\mathrm{km}$ prenuptial movement was also ex-natal (Fig. 2). The ex-natal movements of the other 24 buzzards $(96 \%)$ were entirely separate from movements associated with breeding activity.

For the 25 birds that paired, movement was most likely if there was much deciduous woodland within $500 \mathrm{~m}$ of their focal point the previous winter $(G$ $=5.13$, d.f. $=1, P<0.05$ ), with some improvement if there was little long grass within $1 \mathrm{~km}(G=12 \cdot 93$, d.f. $=2, P<0 \cdot 01$ ), but the effect of neither variable alone exceeded the $1 \%$ level. There was no such relationship for the 14 buzzards that bred. However, the distance moved by all buzzards that paired was greatest for those with most arable land within $1 \mathrm{~km}$ $\left(r_{23}=+0 \cdot 43, P<0 \cdot 05\right)$.

(C) 2001 British Ecological Society, Journal of Animal Ecology, 70, $1-13$

\section{POST-NUPTIAL MOVEMENTS}

Post-nuptial movement was infrequent. Among 12 buzzards that were radio-tracked after breeding, only one moved more than $1 \mathrm{~km}$. This male had already moved $57 \mathrm{~km}$ to the northeast of the study site, into an area with a low buzzard density, where it paired in its second year without a nest being recorded. It bred successfully the following summer, after a postnuptial movement of $1.92 \mathrm{~km}$.

\section{Discussion}

A number of factors are likely to affect decisions about whether to leave a natal area or home range, and then how far to go before settling. Genetic factors, social pressures, habitat quality and experience may all be involved to greater or lesser extents for each individual. This makes it very hard to tease apart the mechanisms involved. We sought factors that may have affected decisions by investigating the timing and scale of impacts. Buffers of $500 \mathrm{~m}$ or smaller around nests or focal areas were our best representation of range cores, with 2-km buffers representing larger areas visited during excursions or when starting a dispersal movement. We assume, as for analyses of habitat availability in circular buffers round individual locations (Arthur et al. 1996), that small buffers are most immediately relevant to the animals.

When possible effects of 20-23 explanatory variables are being assessed, the high risk of false positive statistical errors makes it important to focus on multivariate analyses that give results at the $1 \%$ level. When multivariate results are summarized (Table 2), patterns of impact, timing and scale emerge. Among factors that appeared at least twice, some always promoted movement: these included presence of siblings, grass-heathland and long grass. In contrast, presence of short grass and loamy soil always discouraged movement. However, some effects varied with time. For example, arable land initially discouraged movement strongly and later favoured it. Another variation in impact with time occurred for social factors, which were especially strong in terms of sibling presence during initial ex-natal dispersal, became less marked than habitat effects later in the autumn, but were again strong for non-breeder or nest density in spring. It is clearly important to investigate effects of the environment in different seasons, as well as in different years (Schooley 1994).

Some of these effects were consistent with knowledge of buzzards and other species. Large brood size promoted ex-natal dispersal in tits (Nilsson 1989), and much territorial activity occurs among buzzards in spring (Tubbs 1974; Weir \& Picozzi 1975; Picozzi $\&$ Weir 1976), when movements were again associated with density of nests or non-breeders. The tendency for buzzards to move east as they got older (Fig. 5) probably also reflected social factors, because buzzard density was lower to the east of our study area (Gibbons, Reid \& Chapman 1993). Buzzards spend much time eating worms and other invertebrates (Dare 1957); a generalist diet is enabled by the

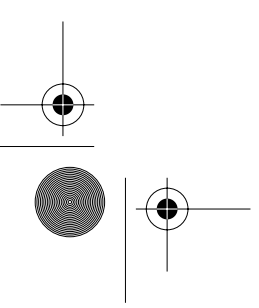


R.E. Kenward,

S.S. Walls \&

K.H. Hodder

high digestive efficiency of these raptors (Barton \& Houston 1993). Worms are rare in acid heathland soils, are most abundant in loam soils (Guild 1951; Lee 1985), and are likely to be less accessible in long grass than where grass is short. Short grassland showed little correlation with other habitats (Table 3). However, LCMGB categories of long and short grassland often occurred together in the same field, which suggested that the remote mapping recorded differences in land cover that were not a simple distinction between mown/grazed areas (Appendix I) and meadows or other natural grassland (Hodder 2000).

The lack of movements from arable areas in autumn and a tendency for buzzards dispersing in autumn to settle in areas with much arable habitat (Walls et al. 1999), probably reflected easy foraging for invertebrates in newly ploughed fields (Dare 1957). Arable land in the 2-km buffer might also have been serving as a proxy for general farmland, as opposed to heathland and other habitats that had strong negative correlations with arable in the $2-\mathrm{km}$ buffer (Table 3). However, movements not only related more tightly to the combination of arable land and grassland than to heathland, but were also strongest with the accurate representation of arable land in the 1-km annual field surveys. In the LCMGB data, cultivation would have changed in some fields during the $1-5$ years since the Landsat images were recorded. In the following spring, on the other hand, there was a strong tendency for buzzards to move if they had much arable land in core areas (Table 2, Fig. 4). Moreover, presence of arable land increased the distance birds moved before pairing. Worm abundance is substantially reduced in arable land, especially with continuous cropping, compared to permanent pasture (Fraser et al. 1996; Edwards \& Bohlen 1996). It seems that arable land became unfavourable habitat when no longer freshly ploughed and functioned as a poison chalice for young buzzards. They were attracted to settle in arable areas in autumn but had to leave in spring.

Weak relationships $(0.05>P>0.01)$ that reversed direction may represent Type 1 errors, especially the tendency of birds to move before pairing if they had little long grass around their winter focal points. A tendency not to travel far from areas rich in conifers (Table 2) was present for separate sets of young birds leaving in summer and autumn (combined $P<0.005$ ), and might represent an initial tendency to use conifer woods for cover because of subordinate status to older birds (Hohmann 1994). Scrub is favoured in buzzard home ranges (R. E. Kenward et al. unpublished), probably for hunting vertebrate prey, but the

C) 2001 British Ecological Society, Journal of Animal Ecology, 70, $1-13$ relationship of movements to scrub was ambiguous (Table 2).

A final pattern evident in Table 2 is that of scale. Among 12 records of effects that were associated with movements most strongly at larger scales than the $1 / 2-\mathrm{km}$ buffer, eight favoured lack of movement. In contrast, among the nine records of effects that were associated with movements most strongly in $1 / 2$ $\mathrm{km}$ buffers, seven favoured movement. Small-scale effects tended to act by repelling birds, short grassland being the only exception. Moreover, four of those repellent small scale effects (from grass heathland, long grassland and arable land) correlated strongly with distances travelled (e.g. Fig. 4), rather than with tendency to move at all. It is remarkable that conditions in the immediate vicinity of birds had such strong effects on the distance travelled when they left. It is hard to conceive an explanation for this other than that the conditions were priming them in some way to travel far. Were the effects confined to extra-natal movements, an explanation might be that the quality of birds that settled in particular habitats was associated with a tendency to move again Indeed, this could explain the tendency of birds that had travelled far by winter to move far again in spring. However, some of the strongest small-scale effects on movement were for the initial ex-natal dispersal movement, when the initial distance travelled increased for small broods with much heath and little short grass close to the nest. At the least, the tendency to move was primed by conditions at the nata nest, and then made the distant travellers either especially sensitive to poor habitat or more prone to encounter it.

Nevertheless, although movement distances were strongly explained by local habitat and previous movements after the first autumn, when distances travelled were relatively short (Fig. 2, Table 2), less than half the variation in ex-natal distances was explained for the first autumn, when distances were greatest. Perhaps genetic factors were involved at this time (Johnson \& Gaines 1990), reflecting a polymorphism in dispersal tendency due to enhanced survival of distant dispersers in severe winters and partly masking identification of local predictors. On the other hand, perhaps weather conditions that favoured thermal development in autumn could have affected the distances travelled and added undetected variance to our data. Further variance might have been explained if data on habitat heterogeneity within the circular buffers had been available. It is important for colonization modelling to understand the mechanisms involved, because long-distance dispersers also tended to breed early (Walls \& Kenward 1998), so inheritance of a travelling trait could accelerate the recolonization. Mechanistic modelling should also take account of possible priming mechanisms, perhaps based on poor reserve accumulation or on adreno-cortico developments.

On the other hand, modelling is simplified by absence of evidence for lengthy movements to breed (R. E. Kenward, A. B. South, S. P. Rushton, S. S. Walls \& K. H. Hodder, unpublished). In their second spring, movements made by buzzards immediately prior to
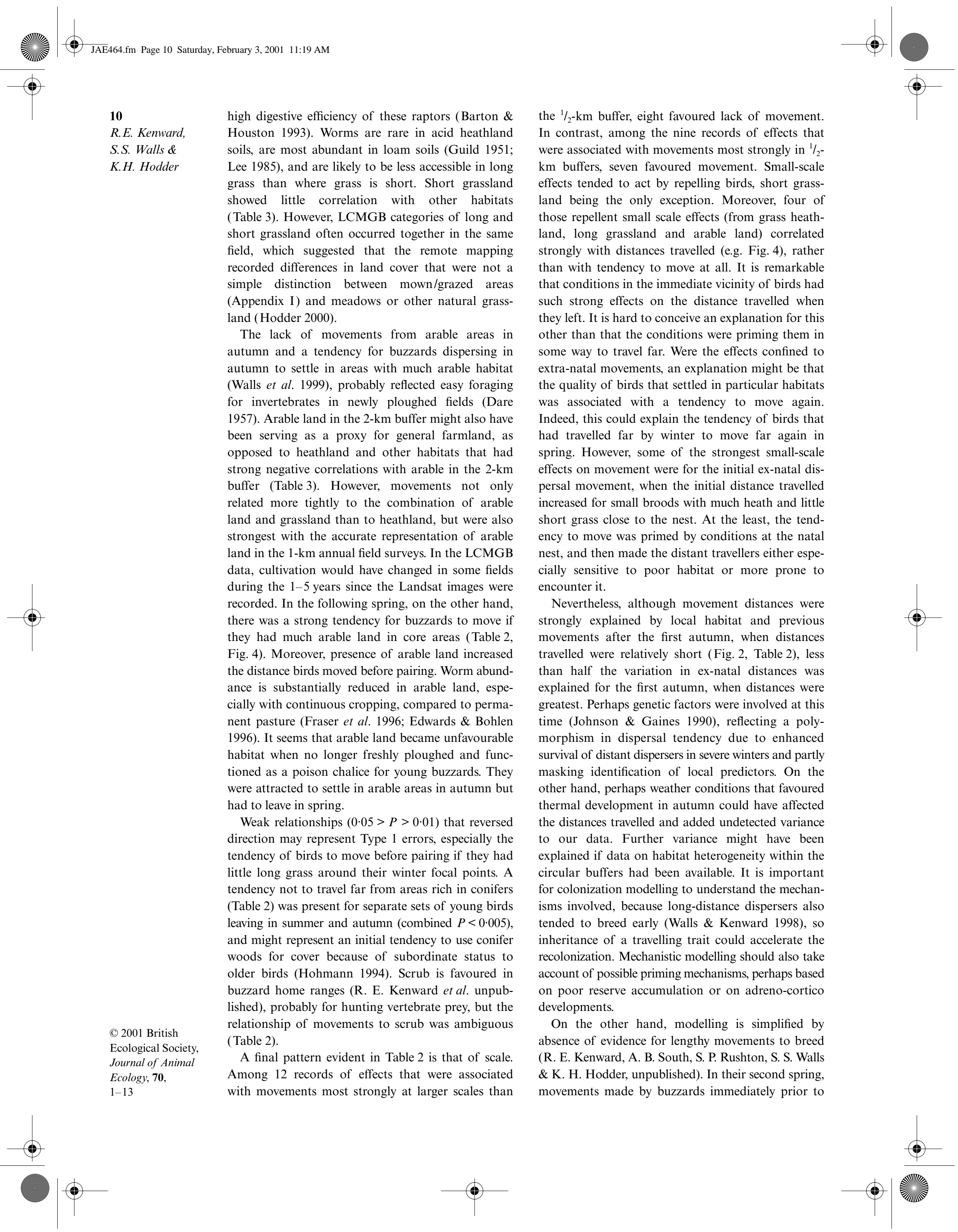
Life path analysis pairing did not differ in length or associated factors from those of buzzards that did not pair. Moreover, movements that resulted in pairing after the second spring were shorter than for unpaired birds (Fig. 6). Thus, we have no grounds other than potential sexual maturity for separating a category of prenuptial movements from other extra-natal transition movements. This suggests that buzzards changed home range for reasons other than mating, and then sometimes found a mate coincidentally. Alternatively, movements specifically to mate were too rare to be detectable, representing another problem of analysing movements, in the tail of a dispersal distribution, which may be rare, but nonetheless important for genetic or colonization processes (Turchin 1998).

We recorded only one post-nuptial movement and none more than $1 \mathrm{~km}$ after successful breeding. The sample size of 12 was small because few buzzards were paired for two seasons before their radios expired. However, post-nuptial movements were also rare in wing-tagged red kites (Milvus milvus) (Newton, Davis \& Davis 1987), were not recorded among 547 buzzard ring recoveries and were very small in most other species examined by Paradis et al. (1998). Exceptions were migratory species (see also Wiklund 1996) or those whose crucial habitats were patchy and life-paths known to involve much travel, such as water birds and especially gulls that transferred between coastal colonies (Greenwood \& Harvey 1982).

Relationships have been recognized for a number of bird species between distances travelled and widespread conditions, such as abundance of prey (Newton 1979). However, these general conditions could represent resource shortage in areas traversed when dispersing. Relationships between distances travelled and habitat conditions that were stronger in core areas than peripheral areas before departure, and therefore indicate priming, seem not to have been noted. This may reflect the fact that although individuals of a few species have been monitored in detail before and during dispersal (e.g. Macdonald 1983; Ferrer 1993; Larsen \& Boutin 1994) large samples have not previously been examined in relation to scaled landscape data in their areas of origin.

\section{Acknowledgements}

This work was funded by the Natural Environment Research Council and Biotrack, with contributions from the Royal Society for the Protection of Birds and English Nature. We would like to thank Robin Fuller with Sue Wallis for providing the LCMGB, and all the landowners who kindly let us tag and track buzzards. We are grateful to Amber Budden, Phillip Harvell, Simon Holloway and Adam Kelly for help with fieldwork, to Patrick Leigh-Fermor for advice on terminology and to Alan Morriss for flying our missions to locate distant dispersers. The manuscript was improved by James Bullock, Richard Caldow, David Macdonald, Nigel Webb and an anonymous referee.

\section{References}

Alonso, J.C., Gonzalez, L.M., Heredia, B. \& Gonzalez, L. (1987) Parental care and the transition to independence of Spanish Imperial eagles Aquila heliaca in Donana National Park, south-west Spain. Ibis, 129, 212-224.

Arthur, S.M., Manly, B.F.J., McDonald, L.L. \& Garner, G.W. (1996) Assessing habitat selection when availability changes. Ecology, 77, 215-227.

Baker, R.R. (1978) The Evolutionary Ecology of Animal Migration. Hodder \& Stoughton, London.

Barton, N.W.H. \& Houston, D.C. (1993) A comparison of digestive efficiency in birds of prey. Ibis, 135, 363-371.

Burt, W.H. (1943) Territoriality and home range concepts as applied to mammals. Journal of Mammalogy, 24, 346-352. Bustamente, J. \& Hiraldo, F. (1990) Factors influencing family rupture and parent-offspring conflict in the black kite Milvus migrans. Ibis, 132, 58-67.

Cooper, W.E. (1978) Home range size and population dynamics. Journal of Theoretical Biology, 75, 327-337.

Dare, P.J. (1957) The post-myxomatosis diet of the buzzard. Devon Birds, 10, $2-6$.

Davies, N.B. (1976) Parental care and the transition to independent feeding in the young spotted fly-catcher (Muscicapa striata). Behaviour, 59, 280-295.

Davies, N.B. (1978) Parental meaness and offspring independence: an experiment with hand reared great tits Parus major. Ibis, 120, 509-514.

Doncaster, C.P. \& Macdonald, D.W. (1991) Drifting territoriality in the red fox Vulpes vulpes. Journal of Animal Ecology, 60, 423-439.

Dunstan, T.C. (1972) A harness for radio tagging raptorial birds. Inland Bird-Banding News, 44, 4-8.

Eden, S.F. (1987) Natal philopatry of the magpie Pica pica. Ibis, 129, 477-490.

Edwards, C.A. \& Bohlen, P.J. (1996) Biology and Ecology of Earthworms. Chapman \& Hall, New York.

Ferrer, M. (1993) Ontogony of dispersal distances in young Spanish imperial eagles. Behavioural Ecology and Sociobiology, 32, 259-263.

Fraser, P.M., Williams, P.H. \& Haynes, R.J. (1996) Earthworm species, population size and biomass under different cropping systems across the Canterbury Plains, New Zealand. Applied Soil Ecology, 3, 49-57.

Fuller, R.M., Groom, G.B. \& Jones, A.R. (1994a) The Land Cover Map of Great Britain: an automated clasification of Landsat Thematic Mapper data. Photogrammatic Engineering and Remote Sensing, 60, 553-562.

Fuller, R.M., Groom, G.B. \& Wallis, S.M. (1994b) The availability of Landsat TM images for Great Britain. International Journal of Remote Sensing, 15, 1357-1362.

Fuller, R.M., Wyatt, B.K. \& Barr, C.J. (1998) Countryside survey from ground and space: different perspectives, complementary results. Journal of Environmental Management, 54, 101-126.

Gautestad, A.O. \& Mysterud, I. (1995) The home range ghost. Oikos, 74, 195-204.

Gibbons, D., Reid, J. \& Chapman, R. (1993) The New Atlas of Breeding Birds in Britain and Ireland 1988-91. T. \& A.D. Poyser, Berkenhamstead.

Glover, B. (1952) Movements of birds in South Australia South Australia Ornithology, 20, 82-91.

Gonzalez, L.M., Heredia, B., Gonzalez, J.L. \& Alonso, J.C. (1989) Juvenile dispersal of Spanish imperial eagles. Journal of Field Ornithology, 60, 369-379.

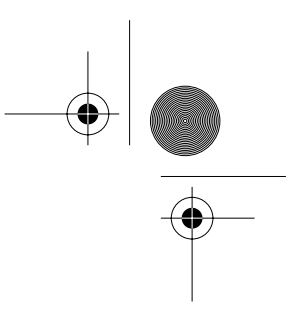

. 
R.E. Kenward,

S.S. Walls \&

K.H. Hodder
(C) 2001 British Ecological Society, Journal of Animal Ecology, 70, $1-13$
Goss-Custard, J.D., Caldow, R.W.G., Clarke, R.T., Le, V., Dit Durrell, S.E.A. \& Sutherland, W.J. (1995a) Deriving population parameters from individual variations in foraging behaviour. I. Empirical game theory distribution model of oystercatchers Haematopus oestralegus feeding on mussels Mytilus edulis. Journal of Animal Ecology, 64, 265-276.

Goss-Custard, J.D., Caldow, R.W.G., Clarke, R.T. \& West, A.D. (1995b) Deriving population parameters from individual variations in foraging behaviour. II. Model tests and population parameters. Journal of Animal Ecology, 64, 277-289.

Greenwood, P.J. (1980) Mating systems, philopatry and dispersal in birds and mammals. Animal Behaviour, 28, $1140-1162$.

Greenwood, P.J. \& Harvey, P.H. (1982) The natal and breeding dispersal of birds. Annual Review of Ecology and Systematics, 13, 1-21.

Guild, W.J. McL. (1951) The distribution and population of earthworms (Lumbricideae) in Scottish pasture fields. Journal of Animal Ecology, 20, 88-97.

Haig, S.M. \& Orring, L.W. (1988) Distribution and dispersal in the piping plover. Auk, 105, 630-638

Hodder, K.H. (2000) The common buzzard in lowland UK: relationships between food availability, habitat use and demography. $\mathrm{PhD}$ thesis, Southampton University.

Hohenstaufen, F. von (1248) De arte venandi cum avibus. Manuscript.

Hohmann, U. (1994) Status specific habitat use in the common buzzard Buteo buteo. Raptor Conservation Today (eds B.-U. Meyburg \& R.D. Chancellor), pp. 359-366. World Working Group on Birds of Prey and Owls, Berlin.

Holleback, M. (1974) Behavioural interactions and the dispersal of the family in black-capped chikadees. Wilson Bulletin, 86, 466-468.

Howard, W.E. (1960) Innate and environmental dispersal of individual vertebrates. American Midland Naturalist, 63, 152-161.

James, F.C. \& McCulloch, C.E. (1990) Multivariate analysis in ecology and systematics: panacea or Pandora's Box? Annual Review of Ecology and Systematics, 21, 129-166

Jennrich, R.J. \& Turner, F.B. (1969) Measurement of noncircular home range. Journal of Theoretical Biology, 22, 227-237.

Johnson, M.L. \& Gaines, M.S. (1990) Evolution of dispersal: theoretical models and empirical tests using birds and mammals. Annual Review of Ecology and Systematics, 21, mammals.

449-480.
Kenward, R.E. (1978) Radio-transmitters tail-mounted on

hawks. Ornis Scandinavica, 9, 220-223.

Kenward, R.E. (2001) A Manual for Wildlife Radio Tagging. Academic Press, London.

Kenward, R.E., Clarke, R.T., Hodder, K.H. \& Walls, S.S. (in press) Distance and density estimators of home range: defining multi-nuclear cores by nearest-neighbor clustering. Ecology, in press.

Kenward, R.E. \& Hodder, K.H. (1996) Ranges V. An Analysis System for Biological Location Data. Institute of Terrestrial Ecology, Wareham.

Kenward, R.E., Marcström, V. \& Karlbom, M. (1993) Post-nestling behaviour in goshawks, Accipiter gentilis. I. The causes of dispersal. Animal Behaviour, 46, 365-370.

Larsen, K.W. \& Boutin, S. (1994) Movements, survival and settlement of red squirrels (Tamiasciurus hudsonicus) offspring. Ecology, 75, 214-223.

Lee, K.E. (1985) Earthworms: Their Ecology and Relationships with Soils and Land Use. Academic Press, Sydney.
Lidicker, WZ \& Stenseth, N.C. (1992) To disperse or not to disperse: who does it and why? Animal Dispersal: Small Mammals as a Model (eds N.C. Stenseth \& W.Z. Lidicker) pp. 21-35. Chapman \& Hall, London.

Macdonald, D.W. (1983) The ecology of carnivore socia behaviour. Nature, 301, 379-384.

Maxwell, A.E. (1961) Analysing Qualitative Data. Methuen, London.

Newton, I. (1979) Population Ecology of Raptors. Poyser, Berkhamsted.

Newton, I., Davis, P.E. \& Davis, J.E. (1989) Age of first breeding, dispersal and survival of red kites Milvus milvus in Wales. Ibis, 131, 16-21.

Nilsson, J.Å. (1989) Causes and consequences of natal dispersal in the marsh tit, Parus palustris. Journal of Animal Ecology, 58, 619-636.

Nilsson, J.Å. (1990) Family flock break-up: spontaneous dispersal or parental aggression. Animal Behaviour, 40 1001-1003.

Paradis, E., Baillie, S.R., Sutherland, W.J. \& Gregory, R.D. (1998) Patterns of natal and breeding dispersal in birds Journal of Animal Ecology, 67, 518-536.

Picozzi, N. \& Weir, D.N. (1976) Breeding biology of the buzzards in Speyside. British Birds, 67, 199-210.

Rushton, S.P., Lurz, P.W.W., Fuller, R. \& Garson, P.J. (1997) Modelling the distribution of the red and grey squirrel at the landscape scale: a combined GIS and population dynamics approach. Journal of Applied Ecology, $\mathbf{3 4}$ 1137-1154.

Schooley, R.L. (1994) Annual variation in habitat selection: patterns concealed by pooled data. Journal of Wildlife Management, 58, 367-374

Spencer, W.D. \& Barrett, R.H. (1984) An evaluation of the harmonic mean method for evaluating carnivore activity areas. Acta Zoologica Fennica, 171, 255-259.

Sutherland, W.J. (1996) From Individual Behaviour to Population Ecology. Oxford University Press, Oxford.

Sutherland, W.J. \& Allport, G.A. (1994) A spatial model of the interaction between bean geese and wigeon with the consequences for habitat management. Journal of Animal Ecology, 63, 51-59.

Tubbs, C.R. (1974) The Buzzard. David and Charles, London.

Turchin, P. (1998) Quantitative Analysis of Movement. Sinauer Associates, Sunderland.

Tyack, A.J., Walls, S.S. \& Kenward, R.E. (1998) Behaviour in the post-nestling dependence period of radio tagged common buzzards Buteo buteo. Ibis, 140, 58-63.

Walls, S.S. \& Kenward, R.E. (1995) Movements of radio tagged buzzards Buteo buteo in their first year. Ibis, 137, 177-182.

Walls, S.S. \& Kenward, R.E. (1998) Movements of radio tagged buzzards Buteo buteo in early life. Ibis, 140, 561-568.

Walls, S.S., Mañosa, S., Fuller, R.M., Hodder, K.H. \& Kenward, R.E. (1999) Is early dispersal enterprise or exile? Evidence from radio tagged buzzards. Journal of Avian Biology, 30, 407-415.

Warkentin, I.G. \& James, P.C. (1990) Dispersal terminology: changing definitions in midflight? Condor, 92, 802-803.

Weir, D.N. \& Picozzi, N. (1975) Aspects of social behaviour in the buzzard. British Birds, 68, 125-141.

White, G.C. \& Garrott, R.A. (1990) Analysis of Wildlife Radio-Tracking Data. Academic Press, New York.

Wiklund, C.G. (1996) Determinants of dispersal in breeding merlins (Falco columbarius). Ecology, 77, 1620-1927.

Received 29 September 1999; revision received 25 February 2000
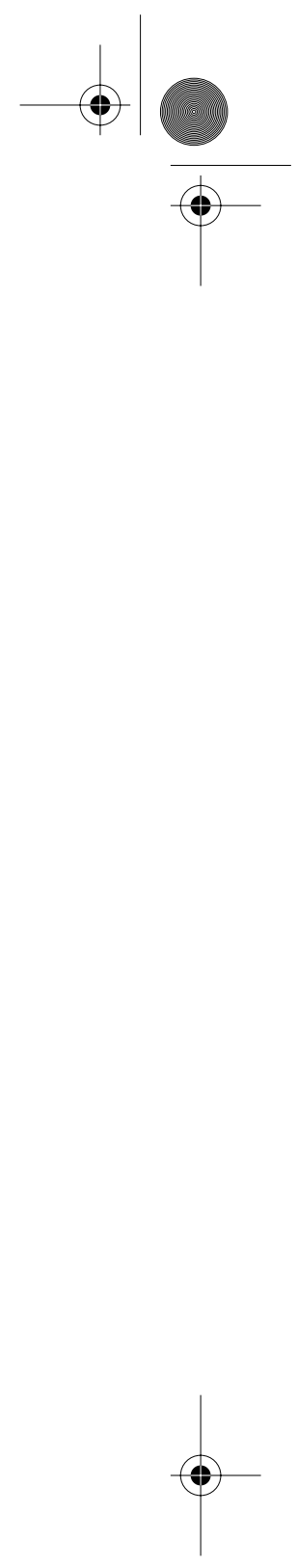
13

Life path analysis

\section{Appendix 1}

Land cover combinations used for assessing the effect of the environment on dispersal of common buzzards.

\begin{tabular}{lcl}
\hline Land cover category & LCMGB class & Description of LCMGB class \\
\hline Water & 1 & Sea/estuary \\
Coast & 2 & Inland water \\
& 3 & Beach and coast bare \\
Sparse grass & 4 & Saltmarsh \\
Short grass & 5 & Rough pasture/dune grass \\
Long grass & 6 & Mown/grazed turf \\
Marsh & 7 & Meadow/verge/semi-natural \\
Grass heath & 8 & Rough/marsh grass \\
& 9 & Moorland grass \\
& 17 & Upland bog \\
Shrub heath & 24 & Lowland bog \\
& 25 & Lowland heath grass \\
Bracken & 10 & Open shrub moor \\
Scrub & 13 & Dense shrub heath \\
Deciduous & 11 & Dense shrub moor \\
Coniferous & 9 & Bracken \\
Arable & 14 & Scrub/orchard \\
Buildings & 15 & Deciduous woodland \\
Bare ground & 16 & Coniferous woodland \\
& 18 & Tilled land \\
\hline
\end{tabular}

(C) 2001 British

Ecological Society, Journal of Animal

Ecology, 70,

$1-13$ 